$1-1-1995$

\title{
Richness and abundance of arthropods in the oak canopy of West Virginia's eastern ridge and valley section during a study of the impact of Bacillus thuringiensis with emphasis on macrolepidoptera larvae
}

Linda Butler

Cathy Zivkovich

Bradley E. Sample

Follow this and additional works at: https://researchrepository.wvu.edu/ wv_agricultural_and_forestry_experiment_station_bulletins

\section{Digital Commons Citation}

Butler, Linda; Zivkovich, Cathy; and Sample, Bradley E., "Richness and abundance of arthropods in the oak canopy of West Virginia's eastern ridge and valley section during a study of the impact of Bacillus thuringiensis with emphasis on macrolepidoptera larvae" (1995). West Virginia Agricultural and Forestry Experiment Station Bulletins. 711.

https://researchrepository.wvu.edu/wv_agricultural_and_forestry_experiment_station_bulletins/602 
Richness and Abundance of Arthropods in the Oak Canopy of West Virginia's Eastern Ridge and Valley Section During a Study of Impact of Bacillus thuringiensis with Emphasis on Macrolepidoptera Larvae

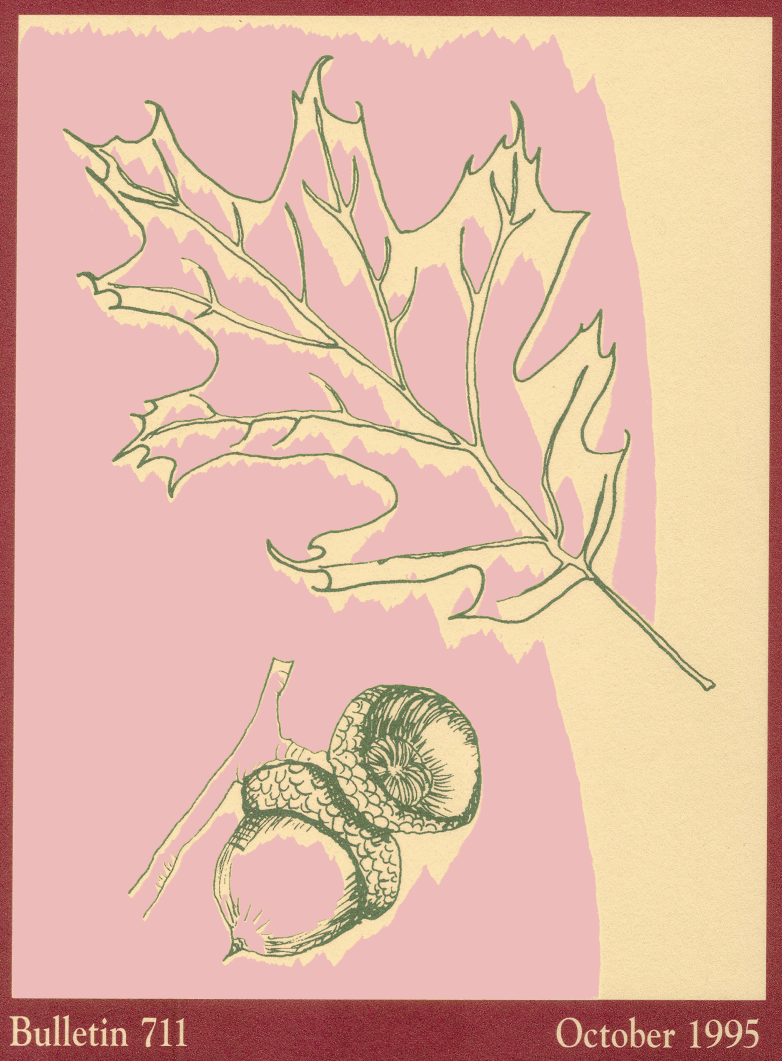

Agricultural and Forestry Experiment Station West Virginia University 


\section{Richness and Abundance of Arthropods in the Oak Canopy of West Virginia's Eastern Ridge and Valley Section During a Study of Impact of Bacillus thuringiensis with Emphasis on Macrolepidoptera Larvae}

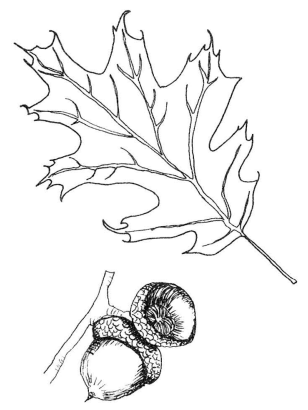

The Authors

Linda Butler and Cathy Zivkovich ${ }^{1}$

Division of Plant and Soil Sciences, West Virginia University and

Bradley E. Sample ${ }^{2}$

Division of Forestry, West Virginia University

${ }^{1}$ We dedicate this paper to our friend and colleague

Cathy Zivkovich who died February 16, 1995.

We miss her.

${ }^{2}$ Current address: Environmental Sciences Division, Oak Ridge

National Laboratory, P.O. Box 2008, Oak Ridge, TN 37831

(Managed by Martin Marietta Energy Systems, Inc., under contract

DE-ACO5-84OR21400 with the U.S. Department of Energy).

West Virginia University

Agricultural and Forestry Experiment Station

College of Agriculture and Forestry

Rosemary R. Haggett, Director

Morgantown 


\title{
Richness and Abundance of Arthropods in the Oak Canopy of West Virginia's Eastern Ridge and Valley Section During a Study of Impact of Bacillus thuringiensis with Emphasis on Macrolepidoptera Larvae
}

\author{
Linda Butler and Cathy Zivkovich \\ Division of Plant and Soil Sciences, West Virginia University \\ and \\ Bradley E. Sample ${ }^{1}$ \\ Division of Forestry, West Virginia University
}

\section{Introduction}

Since its introduction into Massachusetts in 1869, gypsy moth, Lymantria dispar (L.) (Lepidoptera: Lymantriidae) has spread widely and become the most serious defoliator of deciduous trees in the eastern United States. Aerial insecticide applications, particularly diflubenzuron $\left(\right.$ Dimilin $\left.^{\circledR}\right)$ and the bacterial insecticide Bacillus thuringiensis var. kurstaki (Btk) are prominent methods for managing gypsy moth larvae.

Bacillus thuringiensis is a spore-forming bacterium that produces a crystalline toxin during sporulation. Bt var. kurstaki is toxic primarily to larvae of Lepidoptera (Boberschmidt et al. 1989). While the mode of action of Btk gives it considerably more specificity than the more broad spectrum diflubenzuron (Martinat et al. 1988, 1993; Sample et al. 1995; Butler 1995), non-target Lepidoptera (i.e. species not intentionally targeted) are directly susceptible to Btk (Miller 1990 a, b). Indirect effects also have been evaluated on parasitic wasps and flies, mortality resulting when Btk kills the host of the parasitoids (Reardon et al. 1979).

Baseline studies of communities of canopy arthropods in West Virginia were begun in 1983 with greatest emphasis on abundance and richness of larvae of macrolepidoptera (Butler 1992). In this context, abundance refers to total numbers of larvae while richness indicates number of species. These studies were stimulated in large part by the need to document structure of canopy arthropod communities prior to potential alterations of those communities by gypsy moth defoliation or suppression programs. A two-year study at Coopers Rock State Forest $(1983,1984)$ indicated a diverse and abundant community of caterpillars on hardwood foliage (Butler 1992).

Between 1990 and 1992, we evaluated the impact of Btk on all arthropods of oak canopies in Grant and Pendleton counties in West Virginia's Eastern Ridge and Valley Section. Evaluation of impact to the caterpillar community comprised a large portion of that study. We have presented the results of that study as richness and abundance within arthropod taxa on foliage of Btktreated and untreated plots (Sample et al. 1995). Here we present macrolepidoptera larval species and other arthropods on oak foliage for 1990-1992 for treated and untreated plots. 


\section{Materials and Methods}

From 1990 to 1992 data were collected from 24 plots located in the Ridge and Valley region of Grant and Pendleton counties. This area is predominantly forested in oaks (Quercus spp.), hickories (Carya spp.) and pines (Pinus spp.) with a sparse understory of mountain laurel (Kalmia latifolia L.) and blueberry (Vaccinium spp.). Each of the 24 plots was 20 hectares ( 50 acres) in size and situated at elevations from 350 meters to 1150 meters. Similarity of plots was compared by performing vegetation analysis after the method of James and Shugart (1970).

Pretreatment baseline data on foliage arthropod richness and abundance were collected on all plots in 1990. Six plots were sprayed with Btk on May 8, 1991 and six plots on May 10, 1991. Btk was applied as Foray 48B undiluted at a rate of $7.0 \mathrm{~L}$ formulation per hectare $(96 \mathrm{oz} /$ /acre). A single application of Btk was made by helicopter at 15 Billion International Units (BIU)/ha (36 BIU/ acre). The remaining 12 plots served as untreated controls.

Each week from mid-May to early August 1990, 1991 and 199220 to 25 branch tips of foliage of various oak species were taken from low-to midcanopy with pole pruners from two randomly located sites within each of the 24 plots in order to evaluate presence of arthropods in the canopy. Pole pruners were equipped with large plastic catch bags to catch the foliage samples that fell. Following collection, all foliage samples were returned to the laboratory where all arthropods were removed from leaves and stems of the sample; macrolepidopterous larvae were identified to species and other taxa to family or superfamily. Foliage was removed from branch tips, oven dried at $65^{\circ} \mathrm{C}$, weighed and the numbers of arthropods quantified per $50 \mathrm{~g}$ dry foliage weight.

Since the 24 study plots were located in an area of West Virginia with building gypsy moth populations, Lymantria dispar larvae were present on plots and four of the 12 untreated plots showed defoliation of $40 \%$ or more during one or two of the study years. We have evaluated the significance of the defoliation elsewhere (Sample et al. 1995).

Also notable were the differences in weather patterns among the study years. Mean April-August temperatures were greatest in 1991 (mean $=20^{\circ} \mathrm{C}$, $\left.\mathrm{SE}=0.09^{\circ} \mathrm{C}\right)$, intermediate in $1990\left(\right.$ mean $\left.=18.3^{\circ} \mathrm{C}, \mathrm{SE}=1.1^{\circ} \mathrm{C}\right)$ and least in 1992 (mean $16.1^{\circ} \mathrm{C}, \mathrm{SE}=1.3^{\circ} \mathrm{C}$ ). While mean April-August precipitation was least in $1991($ mean $=6.1 \mathrm{~cm}, \mathrm{SE}=0.7 \mathrm{~cm})$, there was no difference between the mean April-August precipitation for 1990 and 1992 (1990: mean $=7.6 \mathrm{~cm}$, $\mathrm{SE}=1.1 \mathrm{~cm} ; 1992:$ mean $=8.3 \mathrm{~cm}, \mathrm{SE}=0.8 \mathrm{~cm})$. Weather factors are known to exert considerable influence on insect populations (Uvarov 1931).

Voucher specimens from the study are deposited in the WVU Arthropod Collection. Species are named and listed after the checklist given by Hodges et al. (1983). 


\section{Results}

Richness and abundance for nontarget macrolepidopterous larvae (i.e. species other than gypsy moth larvae) on untreated and Btk-treated plots are given for 1990 through 1992 (Table 1). In 1990, the pretreatment year, species richness was similar on control (67 species) and treated plots (64 species).

Total nontarget macrolepidoptera larval richness declined to 29 species on the Btk-treated plots in the treatment year (as compared to 46 species on control plots) but was slightly greater on the treated plots than the control plots in the post-treatment year.

Table 1. Richness and abundance of nontarget macrolepidoptera larvae in the oak canopy on Bacillus thuringiensis - treated (T), and control (C) plots. ${ }^{1}$

\begin{tabular}{cccc}
\hline Plots & Year & Richness & Abundance \\
\hline C & 1990 & 67 & 1,086 \\
T & 1990 & 64 & 739 \\
C & 1991 & 46 & 294 \\
T & 1991 & 29 & 148 \\
C & 1992 & 33 & 113 \\
T & 1992 & 38 & 116 \\
\hline Total Richness, Abundance & 91 & 2,496 \\
\hline
\end{tabular}

${ }^{1}$ Bt was applied in May, 1991

Abundance of nontarget macrolepidoptera larvae was 32\% greater on control plots in the pretreatment year, $50 \%$ greater in the treatment year, and $2.5 \%$ less in the post-treatment year. It is noted that abundance declined dramatically over the three years of the study even on the control plots, from 1086 in 1990, to 294 in 1991 and 113 in 1992.

All macrolepidoptera larvae collected during the study are listed in Table 2. Total species richness is 91 , representing 10 families. In addition to yearly totals for treated and control plots and totals for the entire study, we give the earliest and latest dates of collection and the date of peak collection for each species. 
Table 2. Species of macrolepidopterous larvae collected from foliage of mixed oak species: first and last collecting dates of the combined sampling years of 1990-1992, number per year for treated (T) and control (C) plots and total number for the study.

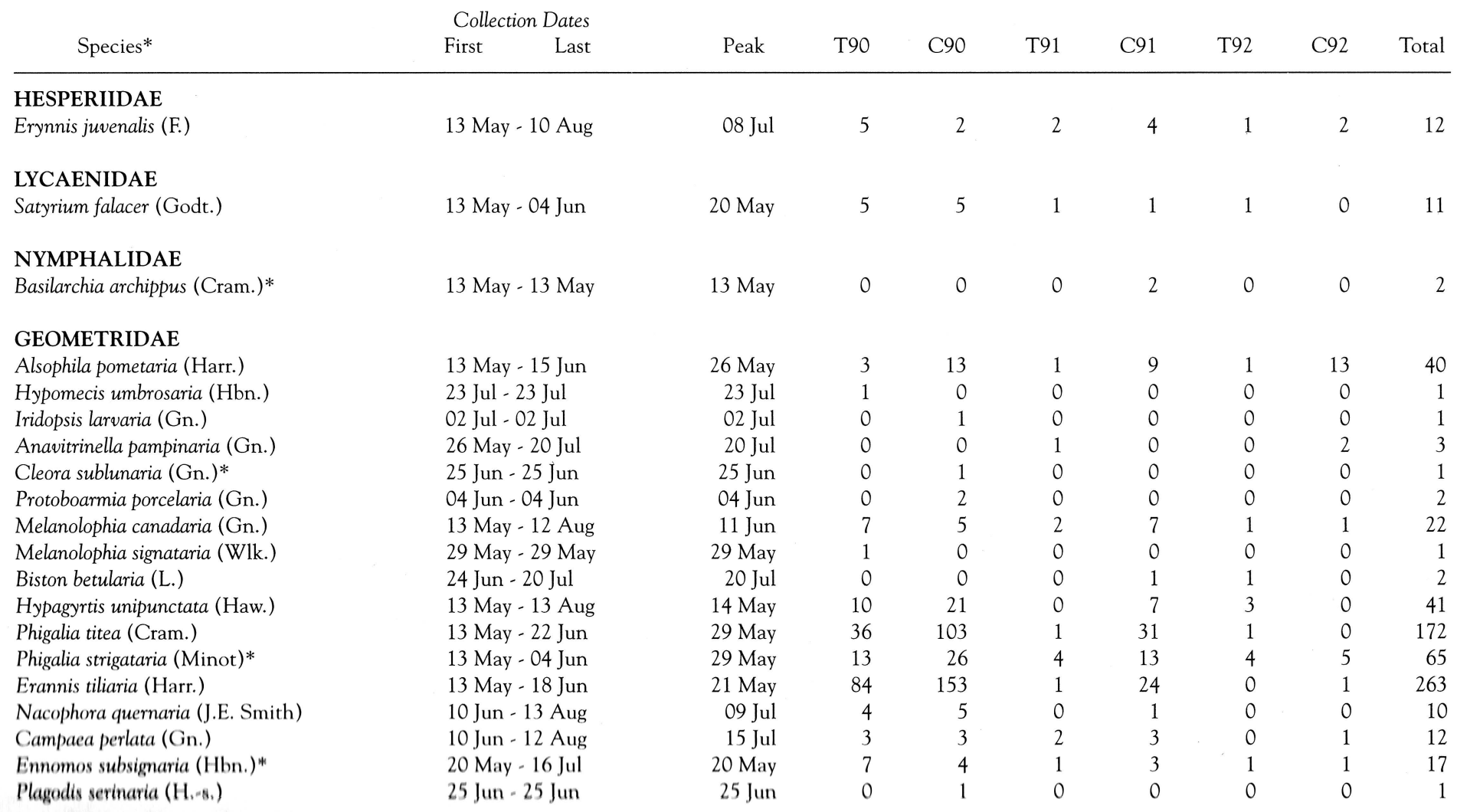


Collection Dates

\section{GEOMETRIDAE}

Plagodis alcoolaria (Gn.)

Besma endropiaria (G. \& R.)

25 Jun - 25 Jun

25 Jun

24 Jun - 13 Aug

26 May - 13 Aug

29 May - 12 Aug

Lambdina fiscellaria $(\mathrm{Gn} .)^{*}$

Tetracis cachexiata (Gn.)

26 May - 13 Aug

14 May - 11 Jun

Nemoria lixaria $(\mathrm{Gn} .)^{*}$

18 Jun - 12 Aug

$14 \mathrm{Jul}$ - 10 Aug

Hydriomena divisaria (Wlk.)*

Eupithecia miserulata (Grt.)

Eupithecia herefordaria (C. \& S.)*

$30 \mathrm{Jul}-30 \mathrm{Jul}$

04 Jun - 25 Jun

29 Jul

26 May

06 Aug

25 Jun

04 Jun

$16 \mathrm{Jul}$

$22 \mathrm{Jul}$

$30 \mathrm{Jul}$

25 Jun

\section{LASIOCAMPIDAE}

\section{Tolype velleda (Stoll)*}

Malacosoma disstria (Hbn.)

03 Aug - 03 Aug

26 May - 17 Jun

03 Aug

29 May

16 Jul - 13 Aug

Anisota senatoria (J.E. Smith)

Anisota virginiensis (Drury)

Hemileuca maia (Drury)*

Antheraea polyphemus (Cram.)

Hyalophora cecropia (L.)*

$16 \mathrm{Jul}$ - 12 Aug

04 Jun - 02 Jul

06 Aug - 06 Aug

$23 \mathrm{Jul}-23 \mathrm{Jul}$

$\begin{array}{rrrrrrrr}\text { 23 Jul } & 134 & 265 & 0 & 0 & 0 & 0 & 399 \\ \text { 30 Jul } & 3 & 46 & 27 & 0 & 0 & 0 & 76 \\ \text { 04 Jun } & 37 & 3 & 0 & 0 & 1 & 0 & 41 \\ \text { 06 Aug } & 1 & 0 & 0 & 0 & 0 & 0 & 1 \\ \text { 23 Jul } & 0 & 1 & 0 & 0 & 0 & 0 & 1\end{array}$

\section{NOTODONTIDAE}

Nadata gibbosa (J.E. Smith)

Hyperaeschra georgica (H.-S.)

Peridea angulosa (J.E. Smith)

Symmerista albifrons (J.E. Smith)*

Macrurocampa marthesia (Cram.)

Heterocampa guttivitta (Wlk.)

11 Jun - 13 Aug

13 May - 10 Aug

05 Aug

13 May

27 Jul - 13 Aug

10 Aug - 10 Aug

24 Jun - 13 Aug

25 Jun - 23 Jul

13 Aug

10 Aug

13 Aug

$30 \mathrm{Jul}$ - 13 Aug

$16 \mathrm{Jul}$

Lochmaeus manteo (Doubleday)

27 Jul - 27 Jul.

12 Aug

$27 \mathrm{Jul}$

25
2
0
0
5
1
5
0

20
0
1
0
7
6
1
0

16
0
0
0
3
0
5
0

5
3
0
0
4
0
4
0

5
2
0
22
3
0
0
0


Collection Dates

\section{ARCTIIDAE}

Hyphantria cunea (Drury)

Halysidota tessellaris (J.E. Smith)

14 May - 12 Aug

08 Jul - 13 Aug

14 May - 14 May 28 May - 13 Aug 14 May - 10 Aug

15 Jun - 15 Jun

13 May - 03 Aug

24 Jun - 22 Jul

06 Aug - 06 Aug

13 May - 11 Jun

29 May - 15 Jun

11 Jun - 11 Jun

14 May - 14 May

21 May - 21 May

13 May - 22 Jun

25 Jun - 09 Jul

13 May - 29 May

23 Jul - 13 Aug

28 May - 28 May

25 Jun - 30 Jul

17 Jun - 13 Aug

09 Jul - 16 Jul

11 Jun - 11 Jun

13 May - 25 Jun

13 May - 15 Jun

21 May - 02 Jul

21 May - 21 May
12 Aug

13 Aug

5
8

4

17

9
2

14 May

06 Aug

29 May

15 Jun

13 May

24 Jun

06 Aug

29 May

29 May

11 Jun

14 May

21 May

21 May

25 Jun

13 May

$30 \mathrm{Jul}$

28 May

25 Jun

13 Aug

09 Jul

11 Jun

14 May

21 May

11 Jun

21 May

Lithophane querquera (Grt.)*

$\begin{array}{rrrrrrr}1 & 0 & 0 & 0 & 0 & 0 & 1 \\ 6 & 5 & 3 & 2 & 0 & 0 & 16 \\ 2 & 2 & 0 & 1 & 1 & 0 & 6 \\ 0 & 0 & 0 & 0 & 0 & 1 & 1 \\ 88 & 422 & 15 & 724 & 127 & 704 & 2080\end{array}$


Collection Dates

Species*

First Last

Peak

T90

C90

T91

C91

T92

C92

Total

Lithophane antennata (Wlk.)*

13 May - 08 Jun

29 May - 29 May

07 Jul - 07 Jul

14 May - 14 May

21 May - 11 Jun

14 May - 11 Jun

14 May - 29 May

21 May - 29 May

13 May - 01 Jun

13 May - 11 Jun

14 May - 14 May

03 Jun - 13 Aug

20 May - 08 Jun

01 Jun - 01 Jun

14 May - 22 Jun

13 May - 29 Jun

01 Jun

29 May

07 Jul

14 May

04 Jun

18 May

14 May

21 May

21 May

29 May

14 May

$09 \mathrm{Jul}$

21 May

01 Jun

29 May

Orthosia alurina (Sm.)*

Orthosia hibisci (Gn.)

Himella intractata (Morr.)

14 May - 11 Jun

21 May

04 Jun

29 May - 07 Jul

29 May

Morrisonia confusa (Hbn.)

20 May - 13 Aug

$20 \mathrm{Jul}$

$\begin{array}{rr}7 & 3 \\ 0 & 2 \\ 0 & 0 \\ 1 & 0 \\ 2 & 2 \\ 11 & 17 \\ 8 & 11 \\ 0 & 1 \\ 2 & 6 \\ 8 & 7 \\ 1 & 1 \\ 14 & 19 \\ 4 & 2 \\ 0 & 0 \\ 4 & 6 \\ 59 & 112 \\ 1 & 2 \\ 0 & 3 \\ 25 & 16\end{array}$

0
0
0
0
0
5
0
0
0
0
0
7
0
0
0
5
0
0
13

* Species not collected as larvae at Coopers Rock State Forest (Butler 1992). 
Species were primarily Noctuidae ( 39 species) and Geometridae ( 27 species). The most abundant macrolepidoptera larvae during the study were the Geometridae Phigalia titea (Cram.), P. strigataria (Minot) and Erannis tiliaria (Harr.); the Saturniidae Anisota senatoria (J.E. Smith) and A. virginiensis (Drury); the Notodontidae Nadata gibbosa (J.E. Smith) and the Noctuidae Orthosia hibisci (Gn.), Acronicta ovata Grt., Morrisonia confusa (Hbn.), Polia latex (Gn.) and Amphipyra pyramidoides Gn. Several of these species, most especially the early season geometrids and noctuids declined on the Btk-treated plots. Abundance for many of these species was higher on untreated plots in the pretreatment year as well.

Dates of first collection and last collection for the larvae represent limitations of foliage sampling effort over the seasons. Sampling began the second week of May (May 13) soon after leaf expansion of oak began on the plots, and ended in mid-August each year. Larval species that were feeding on oaks on the plots before or after these sampling periods were not represented.

In addition to 10 families of macrolepidoptera larvae found on the oak foliage, 190 other taxa (primarily families) were identified (Table 3). The most abundant families were Aphididae, Curculionidae, Tenthredinidae, Pergidae, Coccidae, Cicadellidae, Reduviidae, Miridae, Formicidae and Elateridae. All are herbivores with the exception of the predatory reduviids and the omnivorous formicids. The numbers of Aphididae fluctuated from high levels in 1991 to relatively low in 1990 and 1992. A similar pattern was noted for the Coccidae, Cicadellidae and Miridae, all plant juice feeders. The chewing herbivores Curculionidae, Tenthredinidae and Pergidae were highest on all plots in 1990 and 1991 and declined in 1992.

The Membracidae were relatively more abundant on all plots in 1991 and 1992 and the Gelechiidae, Linyphiidae, Tortricidae, Chrysomelidae and Philodromidae were in relatively higher numbers on all plots in 1990 and 1991. Families whose numbers remained relatively stable over the three years included Salticidae, Araneidae, Thomiscidae and Dictynidae, all spiders.

Possible effects as related to Bacillus thuringiensis application or gypsy moth defoliation in the absence of insecticide treatment were seen for the Aphididae, Pergidae and Tingidae, herbivores which compete with gypsy moth for food and which are presumably not sensitive to Btk. In the treatment year (1991) numbers for these three families were 44 to $85 \%$ higher on the Btktreated plots. The microlepidoptera families Gelechiidae and Tortricidae were in higher numbers on the control plots during the treatment year but numbers also had been higher on the control plots in the pretreatment year. As a general trend, macrolepidoptera larval numbers for most species were highest in 1990 and declined each year of the study regardless of treatment. Any patterns of increase or decrease in abundance of other arthropod taxa are difficult to discern.

We note that significant differences in temperature and precipitation occurred among the study years; while 1991 was the warmest year during the sampling period and 1992 the coolest, the greatest rainfall occurred in 1990 and in 1992. The treatment year therefore was the warmest and dryest during the three-year study. 
Table 3: Non-macrolepidoptera taxa taken from foliage of mixed oak species: abundance on treated (T) and control (C) plots and total number for the study. Taxa are arranged from most to least abundant.

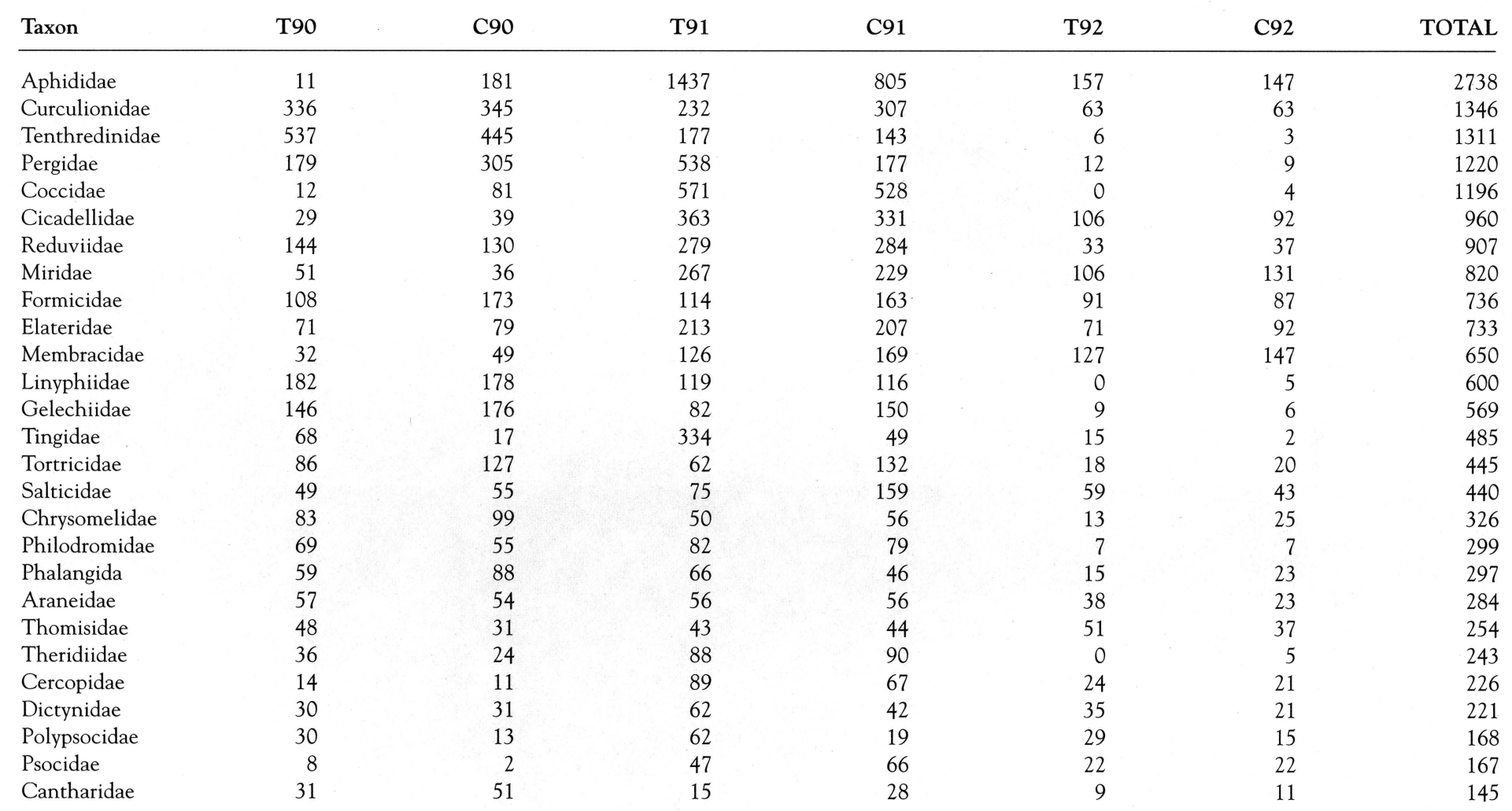




\begin{tabular}{|c|c|c|c|c|c|c|c|}
\hline Taxon & T90 & C90 & T91 & C91 & T92 & C92 & TOTAL \\
\hline Micryphantidae & 31 & 42 & 30 & 11 & 18 & 13 & 145 \\
\hline Pentatomidae & 21 & 22 & 29 & 34 & 10 & 28 & 144 \\
\hline Coccinellidae & 6 & 14 & 38 & 31 & 25 & 27 & 141 \\
\hline Phlaeothripidae & 0 & 2 & 47 & 48 & 18 & 24 & 139 \\
\hline Clubionidae & 29 & 21 & 7 & 6 & 38 & 30 & 131 \\
\hline Mordellidae & 34 & 23 & 23 & 18 & 16 & 14 & 128 \\
\hline Scarabaeidae & 8 & 12 & 24 & 55 & 19 & 9 & 127 \\
\hline Cecidomyiidae & 1 & 3 & 28 & 70 & 3 & 3 & 108 \\
\hline Braconidae & 19 & 20 & 23 & 11 & 20 & 13 & 106 \\
\hline Anyphaenidae & 0 & 0 & 65 & 24 & 12 & 3 & 104 \\
\hline Gryllidae & 8 & 14 & 39 & 27 & 8 & 6 & 102 \\
\hline Chalcidoidea & 6 & 23 & 8 & 22 & 19 & 21 & 99 \\
\hline Tipulidae & 26 & 51 & 6 & 6 & 5 & 3 & 97 \\
\hline Cynipidae & 11 & 14 & 14 & 19 & 11 & 14 & 83 \\
\hline Ichneumonidae & 21 & 33 & 11 & 7 & 3 & 6 & 81 \\
\hline Empididae & 15 & 33 & 5 & 9 & 6 & 8 & 76 \\
\hline Alleculidae & 4 & 18 & 23 & 19 & 4 & 7 & 75 \\
\hline Acrididae & 1 & 3 & 6 & 2 & 26 & 31 & 69 \\
\hline Gracillariidae & 3 & 52 & 2 & 3 & 4 & 1 & 65 \\
\hline Pisauridae & 13 & 8 & 27 & 5 & 7 & 2 & 62 \\
\hline Chironomidae & 6 & 5 & 8 & 12 & 7 & 23 & 61 \\
\hline Hemerobiidae & 3 & 7 & 16 & 21 & 2 & 8 & 57 \\
\hline Heteronemiidae & 6 & 4 & 15 & 11 & 5 & 3 & 44 \\
\hline Eriosomatidae & 0 & 0 & 13 & 29 & 0 & 0 & 42 \\
\hline Anobiidae & 2 & 5 & 8 & 13 & 2 & 11 & 41 \\
\hline Tettigoniidae & 9 & 7 & 5 & 8 & 6 & 5 & 40 \\
\hline Proctotrupoidea & 15 & 11 & 5 & 3 & 0 & 2 & 36 \\
\hline Melyridae & 1 & 0 & 2 & 6 & 16 & 10 & 35 \\
\hline Dolichopodidae & 8 & 10 & 2 & 6 & 3 & 5 & 34 \\
\hline Limacodidae & 2 & 2 & 8 & 15 & 3 & 4 & 34 \\
\hline Cerambycidae & 6 & 9 & 3 & 4 & 1 & 9 & 32 \\
\hline
\end{tabular}


Lauxaniidae

\section{9}

Sciaridae

Cleridae

Mycetophilidae

Anthicidae

Nemouridae

Buprestidae

Lyonetiidae

Staphylinidae

Rhagionidae

Anystidae

Lycidae

Psyllidae

Lygaeidae

Chrysopidae

Syrphidae

Dascillidae

Agromyzidae

Dictyopharidae

Coniopterygidae

Xyelidae

Mycetophagidae

Ptilodactylidae

Entomobryidae

Lampyridae

Pedilidae

Drosophilidae

Siricidae

Leuctridae

Oedemeridae

Lathridiidae
13

3

10

5

14

2

4

2

7

0

7

1

12

4
5
4

1

0

0

30


Taxon

T90

C90

T91

C91

T92

C92

TOTAL

Muscidae

Pyralidae

Chloroperlidae

Cicadidae

Coreidae

Scolytidae

Tachinidae

Derbidae

Lagriidae

Cryptophagidae

Stratiomyidae

Chloropidae

Calliphoridae

Tabanidae

Achilidae

Issidae

Thripidae

Byrrhidae

Phoridae

Asilidae

Anthophoridae

Trombidia

Tineidae

Perlodidae

Aeolothripidae

Colydiidae

Anthomyiidae

Bibionidae

Cixiidae

Delphacidae

Phylloxeridae

$\begin{array}{lll}2 & 4 & 0 \\ 4 & 3 & 0 \\ 1 & 3 & 2 \\ 0 & 0 & 0 \\ 1 & 2 & 1 \\ 0 & 0 & 1 \\ 0 & 1 & 0 \\ 3 & 2 & 0 \\ 1 & 1 & 3 \\ 0 & 0 & 0 \\ 2 & 1 & 0 \\ 0 & 1 & 0 \\ 1 & 1 & 0 \\ 1 & 0 & 1 \\ 1 & 1 & 2 \\ 5 & 0 & 0 \\ 0 & 1 & 2 \\ 1 & 3 & 0 \\ 3 & 1 & 0 \\ 3 & 0 & 0 \\ 0 & 0 & 1 \\ 1 & 0 & 1 \\ 2 & 2 & 0 \\ 0 & 1 & 1 \\ 0 & 0 & 0 \\ 0 & 0 & 1 \\ 0 & 1 & 1 \\ 0 & 2 & 0 \\ 1 & 0 & 1 \\ 0 & 3 & 0 \\ 1 & 0 & \end{array}$

2
1
1
0
1
0
3
1
0
0
2
2
3
1
1
0
2
0
0
0
0
0
0
0
3
0
1
1
0
0
1

0

0




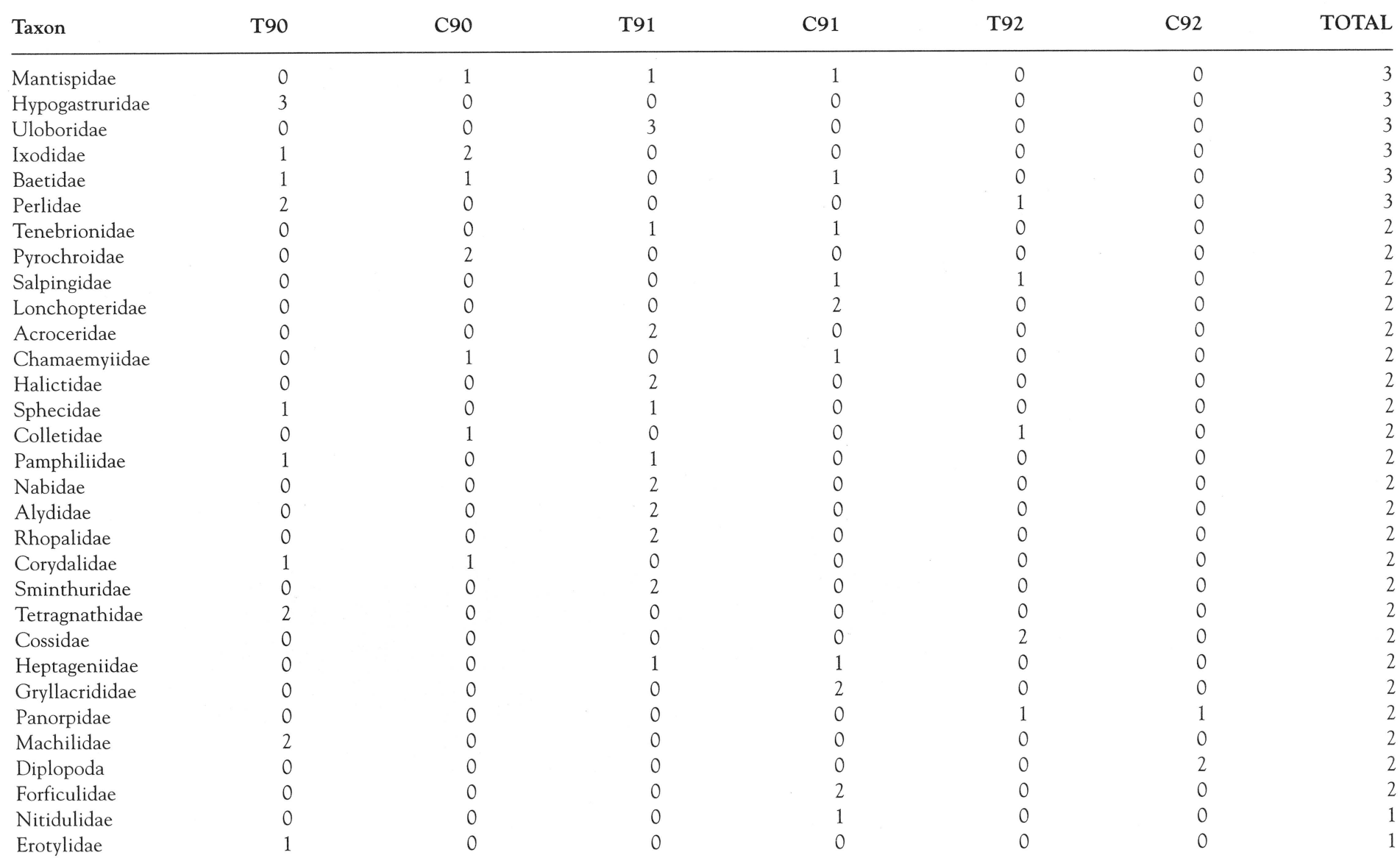


Endomychidae

Bruchidae

Cicindelidae

Lyctidae

Simuliidae

Ceratopogonidae

Psychodidae

Pipinculidae

Culicidae

Sciomyzidae

Xylophagidae

Xylomyidae

Leptogastridae

Piophilidae

$\rightarrow \quad$ Milichiidae

Platygasteridae

Vespidae

Apidae

Bethylidae

Argidae

Cimbicidae

Diprionidae

Aulacidae

Tiphiidae

Pompilidae

Andrenidae

Dilaridae

Hydropsychidae

Goeridae

Amaurobiidae

Agelenidae

\begin{tabular}{|c|c|}
\hline 1 & 0 \\
\hline 0 & 1 \\
\hline 0 & 0 \\
\hline 0 & 0 \\
\hline 0 & 0 \\
\hline 0 & 0 \\
\hline 0 & 1 \\
\hline 1 & 0 \\
\hline 1 & 0 \\
\hline 1 & 0 \\
\hline 1 & 0 \\
\hline 0 & 0 \\
\hline 0 & 0 \\
\hline 1 & 0 \\
\hline 0 & 0 \\
\hline 0 & 1 \\
\hline 0 & 0 \\
\hline 1 & 0 \\
\hline 0 & 0 \\
\hline 1 & 0 \\
\hline 0 & 0 \\
\hline 0 & 0 \\
\hline 1 & 0 \\
\hline 0 & 0 \\
\hline 0 & 0 \\
\hline 0 & 0 \\
\hline 0 & 0 \\
\hline 1 & 0 \\
\hline 1 & 0 \\
\hline 0 & 0 \\
\hline 0 & 0 \\
\hline
\end{tabular}

0
0
0
1
1
0
0
0
0
0
0
0
0
0
1
0
0
0
0
0
0
0
0
0
0
1
0
0
0
1
0

0
0
1
0
0
0
0
0
0
0
0
0
0
0
0
0
1
0
0
0
1
1
0
1
1
0
0
0
0
0
0

0

1

$\begin{array}{lll}0 & 0 & 0 \\ 0 & 0 & 0\end{array}$


Oribatidae

Oecophoridae

Eriocraniidae

Plutellidae

Tetrigidae

0
0
0
0
0
0
0

0
0
0
0
1
1
0

1
0
0
0
0
0
1

0
0
1
1
0
0

0
1
0
0
0
0

0

1
1
1
1
1
1
1




\section{Discussion}

The collection of 91 species of macrolepidoptera larvae on foliage of mixed oaks in West Virginia's Eastern Ridge and Valley Section compares favorably with results of an earlier study by Butler (1992) at Coopers Rock State Forest in the Allegheny Mountain and Upland section of West Virginia. In the earlier study at Coopers Rock State Forest, foliage sampling was conducted for black birch, black cherry, red maple and mixed oaks for a total larval richness of 100 species. Sixty-one of those 100 species were taken on mixed oaks, only 15 of the 61 species being exclusively on oak. The earlier study was conducted for only two years instead of three as in the current study, and the sampling intensity each week from mid-May to mid-August was less on the earlier study. However, in the earlier study, foliage sampling was continued each year until the beginning of leaf fall in October.

Caterpillar species taken during the current study which were not collected as larvae in the 1992 Coopers Rock study include 7 species of geometrids, a lasiocampid, a nymphalid, two saturniids, a notodontid and 22 species of noctuids; these are indicated by an asterisk in Table 2. Of these species, all have been taken as adults (Butler and Kondo 1991; 1993) or as larvae (Butler and Kondo 1993) in other studies at Coopers Rock or nearby in other areas of Monongalia and Preston counties, West Virginia (Butler, unpublished data). The exception would be Hemileuca maia (Drury), a species considered to be more common in the drier oak-pine forests of West Virginia. Some of the species not taken as larvae at Coopers Rock (Butler 1992) were likely in relatively low numbers and would have had a better chance of being represented in collections at higher sampling intensity.

Macrolepidoptera larvae taken at Coopers Rock (Butler and Kondo 1991) not taken in the Bt study were the papilionid Papilio glaucus L.; the geometrids Itame pustularia (Gn.), Glena cribrataria (Gn.), Ectropis crepuscularia (D. and S.), Lomographa glomeraria (Grt.), Probole amicaria (H.S.) and Nemoria mimosaria (Gn.); the saturniid Actias luna (L.); the sphingid, Paonias myops (J.E. Smith); the notodontids Furcula borealis (Guer. - Meneville), Symmerista leucitys Franc. and Oligocentria lignicolor (Wlk.); the arctiid Lophocampa caryae Harr.; and the noctuids Acronicta americana (Harr.), A. fragilis (Gn.), A. increta Morr. and A. inclara Sm. Most of these species do not commonly utilize oak as a host and/or are not often found in high numbers.

During this study, total Lepidoptera richness and abundance and richness and abundance of geometrids and noctuids significantly declined on treated plots during the Btk application year of 1991 (Sample et al. 1995). Numbers of individual species were too low for statistical analyses; however, trends may be noted. The Btk treatments were made 8 and 10 May 1991. Nontarget larvae on plots at that time and soon thereafter appeared to decline. Included were the Geometridae Hypagyrtis unipunctata (Haw.), Phigalia titea, Phigalia strigataria; and Erannis tiliaria; and noctuids Amphipyra pyramidoides, Cosmia calami (Harv.), Lithophane antennata (Wlk.) and Orthosia hibisci. Other early spring species were in such low numbers as to obscure any trends. No difference was noted between numbers of these species on treated and nontreated plots in 1992, the post-treatment year, again in part because of very low numbers of nontarget caterpillars on all plots in that year. 
Caterpillar species which were collected in relatively high numbers beginning late May and for the remainder of the season did not appear to be affected by the Btk application. Included were the geometrid Besma endropiaria (G. \& R.), the saturniid Anisota virginiensis, the notodontid Nadata gibbosa, the arctiid Hyphantria cunea (Drury) and the noctuids Acronicta ovata, Polia latex, and Morrisonia confusa. Btk is known to persist only for a few days on treated foliage (Sundaram and Sundaram 1992).

Since larval numbers declined each year of the study on all plots, factors other than Btk effect must have been responsible. High abundance of predators, parasitoids or diseases may have been responsible for the declines on all plots in 1991 and 1992, but we have no data to support the role of these biotic factors. Weather is another logical possibility. Since we have no data from the plots prior to 1990 , we can see no trends which may have led to the relatively high numbers of nontarget caterpillars on the plots in 1990. Perhaps populations of macrolepidoptera were already declining in 1990 and continued that pattern in later years of the study. Numerous studies have been conducted on direct and indirect effects of weather trends and atypical catastrophic temperature and rain events on insect populations (Martinat 1987). Since 1991 showed the highest mean temperatures and lowest mean rainfall for the April through August period during the three years, we may have expected stable or increasing numbers of some lepidopterous larvae. This would be supported by White (1974) who showed outbreaks of loopers (spring defoliating geometrids) related to drought conditions which stressed host trees and Ives (1973) who related collapses of the forest tent caterpillar, Malacosoma disstria $\mathrm{Hbn}$., to cool springs.

During 1992, macrolepidoptera populations continued to decline on all plots. While mean temperature for April through August that year was the lowest of the three years, mean precipitation was the same for 1992 and 1990. Low spring temperatures have been shown to produce collapse in populations of some caterpillars (Ives 1973).

Among the non-macrolepidopterous taxa taken during the study, the Aphididae were considerably higher on all plots during 1991 than the other years. High temperatures and low rainfall are known to trigger outbreaks in aphid populations (Jones 1979). During 1991 of the Btk study there were much higher numbers of other juice-feeding insects (Coccidae, Cicadellidae and Miridae) on all plots. Drought stress to plants which benefits aphids also may benefit aphid relatives in the same feeding guild.

Through the use of the foliage pruning method with a plastic catch bag we may have lost some of the more active arthropods from the foliage, particularly certain Hymenoptera and Diptera. Thus, we suspect that richness and abundance of arthropods on foliage was higher than we determined, but this loss was presumably consistent for all samples.

Among the chewing herbivores including Curculionidae, Tenthredinidae, Pergidae, Gelechiidae, Tortricidae and Chrysomelidae, lowest numbers were found in 1992, the same year that the macrolepidopterous larvae in the same feeding guild declined so dramatically. Perhaps the same factors are responsible for decline of all groups. Again, direct effects of weather or indirect effects as mediated through the host plants would be implicated since biotic factors such as parasitoids and diseases may not be expected to affect such divergent groups of herbivores. 


\section{Summary}

Diverse macrolepidopterous larval species and arthropod family taxa were found in the oak canopy in West Virginia's Eastern Ridge and Valley Section. Many species and families were represented by very low numbers.

Bacillus thurinigiensis kurstaki produced signficiant decline of macrolepidopterous larvae on treated plots during the treatment year (Sample et al. 1995). We have shown in the paper that the decline occurred in those caterpillar species that were in the oak canopy at the time of Btk application or soon thereafter. There appeared to be no difference in abundance on treatment and control plots for those caterpillar species occurring in mid-and lateseason, i.e. some weeks or months post-treatment. No difference between treated and control plots was shown in abundance for most species in 1992, the post-treatment year; an exception was the early spring defoliator, Alsophila pometaria. However, this species had been more abundant on the untreated plots prior to Btk application. Non-Lepidoptera appeared to suffer no negative effect from the Btk treatment.

Abundance and richness of nontarget macrolepidopterous larvae declined each year of the three year study, even on non-treated plots. Other families of chewing herbivores were in very low abundance also by 1992 . Weather related effects may be responsible for this decline.

\section{References}

Boberschmidt, L., S. Saari, J. Sassaman, and L. Skinner. 1989. Pesticide background statements. Vol. IV. Insecticides. U.S.D.A. Agricultural Handbook. 685.578 pp.

Butler, L. 1992. The community of macrolepidopterous larvae at Coopers Rock State Forest, West Virginia: a baseline study. Can. Entomol. 124:1149-1156.

Butler, L. 1995. Non-target impact of Dimilin to arthropods and implication for impact to vertebrate food chains. Proc. Fifth Ann. Virginia Gyspy Moth Review, Luray, VA, January 31, 1995. pp. 14-18.

Butler, L. and V. Kondo. 1991. Macrolepidopterous moths collected by blacklight trap at Coopers Rock State Forest, West Virginia: a baseline study. WVU Agric. and For. Exp. Sta. Bull. 705, 25 pp.

Butler, L. and V. Kondo. 1993. Impact of Dimilin on nontarget Lepidoptera: Results of an operational gypsy moth suppression program at Coopers Rock State Forest, West Virginia. WVU Agric. and For. Exp. Sta. Bull. 710, 21 pp.

Hodges, R.W., T. Dominic, D.R. Davis, D.C. Ferguson, J.G. Franclemont, E.G. Munroe, and J.A. Powell. 1983. Checklist of the Lepidoptera of America North of Mexico. London. E.W. Classey, Ldt. and Washington, D.C. Wedge Entomol. Res. Found. 284 pp.

Ives, W.G.H. 1973. Heat units and outbreaks of the forest tent caterpillar. Can. Entomol. 105:529-543. 
James, F.C. and H.H. Shugart, Jr. 1970. A quantitative method of habitat description. Audubon Field Notes 24:727-736.

Jones, M.G. 1979. Abundance of aphids on cereals from before 1973 to 1977. J. Appl. Ecol. 16:1-22.

Martinat, P.J. 1987. The role of climatic variation and weather in forest insect outbreaks. pp. 241-268. In: Insect Outbreaks, Ed. P. Barbosa and J.C. Schultz. Academic Press.

Martinat, P.J., C.C. Coffman, K. Dodge, R.J. Cooper, and R.C. Whitmore. 1988. Effect of diflubenzuron on the canopy arthropod community in a central appalachian forest. J. Econ. Entomol. 81:261-267.

Martinat, P.J., D.T. Jennings and R.C. Whitmore. 1993. Effects of diflubenzuron on the litter spider and orthopteroid community in a central appalachian forest infested with gypsy moth (Lepidoptera: Lymantriidae). Environ. Entomol. 22: 1003-1008.

Miller, J.C. 1990a. Field assessment of a microbial pest control agent on nontarget Lepidoptera. Amer. Entomol. 36:135-139.

Miller, J.C. 1990b. Effects of a microbial insecticide, Bacillus thuringiensis kurstaki, on nontarget Lepidoptera in a spruce budworm forest. J. Res. Lepidop. 29:267-276.

Reardon, R.C., W. Metterhouse, and R. Balaam. 1979. Impact of aerially applied Bacillus thuringiensis and carbaryl on gypsy moth (Lepidoptera: Lymantriidae) and adult parasites. Entomophaga 24:305-310.

Sample, B.E., L. Butler, C. Zivkovich, R.C. Whitmore and R. Reardon. 1995. Effects of Bacillus thuringiensis and defoliation by the gypsy moth on native arthropods in West Virginia. Can. Entomol. In Press.

Sundaram, K.M.S. and A. Sundaram. 1992. An insect bioassay method to determine persistence of Bacillus thuringiensis var. kurstaki (B.T.K.) protein in oak foliage, following application under field conditions. J. Environ. Science and Health. B27:73-112.

Uvarov, B.P. 1931. Insects and climate. Trans. Entomol. Soc. London. $74: 1-247$.

White, T.C.R. 1974. A hypothesis to explain outbreaks of looper caterpillars with special reference to populations of Selidosema suavis in a plantation of Pinus radiata in New Zealand. Oecologia 16:279-301. 
Blank Page in Original Bulletin 


\section{Blank Page in Original Bulletin}


